\title{
Det allmänna rättsmedvetandet och några svenska förarbeten på straffrättens område 2008-2018 ${ }^{1}$
}

\author{
Andreas Anderberg, Universitetslektor i straffrätt, Malmö \\ universitet $^{2}$
}

\begin{abstract}
This article focuses on what is often termed the general (or public) sense of justice, GSJ for short. It illustrates the influence that the GSJ has had on various preparatory works in Swedish criminal law during a recent decade. It is often claimed that the GSJ is used as an argument in political discourse and decision making in the area of criminal law, especially to motivate criminalisation and harsher penal sanctions. Political points can be scored and general elections won by deploying a tough stance on crime. A problematic aspect is that by appealing to the GSJ, legislators create a way to legitimise punitive measures with little or no empirical support in criminological research. Furthermore, the very concept of the GSJ is unclear, contentious, and characterised by a plethora of interpretations. This article provides background on the GSJ in the Nordic countries and thereby gives context to some recent legislative work in Sweden. The article concludes that legislators frequently reproduce phrases which, under closer inspection, appear quite hollow. The GSJ therefore seems to be more of a vague reference used for political purposes as opposed to a representation of actual popular values.
\end{abstract}

\section{Keywords}

Sense of justice, legislation, penal populism, rättsmedvetande, lagstiftning, straffpopulism

1. Title in English: The general sense of justice and some Swedish preparatory works in the field of criminal law 2008-2018

2. Artikeln har möjliggjorts genom medel från Ulla V. Bondesons stiftelse för rättssociologisk och kriminologisk forskning för vilket jag härmed framför mitt varma tack. För värdefulla synpunkter på ett tidigare utkast tackas docent Robert Andersson. Tack också till de två anonyma granskarna som kommit med värdefulla insikter. Eventuella kvarvarande brister är förstås mina egna. 


\section{Inledning}

Fiktion eller inte, en viss dragningskraft verkar denna rättslivets lika närvarande som undflyende primadonna utöva.

Hans-Gunnar Axberger

Det är ett ofta upprepat påstående i litteraturen att det allmänna rättsmedvetandet - hädanefter i regel benämnt ARM - spelar en stor roll i samband med lagstiftning på (främst) straffrättens område, företrädesvis för att motivera straffskärpningar och vidta andra åtgärder i repressiv riktning (se t.ex. Blymke, Ryberg 2016, Träskman 2015, Wandall). ARM har ett slags legitimerande funktion genom vilken lagstiftare kan motivera reformer utifrån mer eller mindre vaga referenser till folkviljan. I vilken utsträckning sådana hänvisningar förekommer i förarbeten under senare år och vilken sorts rättsmedvetande det egentligen är tal om är artikelns huvudspörsmål. Inledningsvis sätts ARM i sitt sammanhang genom en redogörelse för hur ARM diskuterats i den nordiska straffrättskontexten under de senaste decennierna, med betoning på den svenska utvecklingen. Syftet är således inte att komma med en specifik precisering av begreppet eller att genom empiriska undersökningar utröna hur ARM ter sig hos allmänheten. Åtskilliga sådana studier har redan utförts. ${ }^{3}$ Därefter exemplifieras hur ARM kommit till uttryck i svenska förarbetena genom en studie av ett antal olika lagmotiv som tillkommit under en tioårsperiod. Avslutningsvis redogörs för de resultat som framkommit och en koppling till den förda diskussionen görs.

Här belyses inte bara det som kan benämnas rättsmedvetandet utan också snarlika begrepp som exempelvis rättskänsla. I en nordisk kontext är det inte märkvärdigt att begreppen blir något olika på grund av de olika språken. Ret $(t)$ sfølelse på danska och norska kan direktöversättas med just rättskänsla, men en känsla kan uppfattas som något tämligen vagt och därmed stå i viss kontrast till rättsmedvetande som indikerar något djupare. I en del texter används i stället retsbevisdhed/rettsbevissthet, men Balvig (2006) menar att retsfølelse är ett snävare begrepp än retsbevisdhed eftersom det senare utöver de attityder som inryms i rättskänslan också innefattar någon typ av kunskap (viden). Även rättsuppfattning används på vissa håll (t.ex. i Strömberg m.fl.) men det har hävdats att rättsuppfattning närmast kan definieras som ett antagande om vad som är gällande rätt, till skillnad från bl.a. rättskänsla som i stället skulle vara vad som är den rätt-

3. För svenskt vidkommande se t.ex. Lindén \& Similä, Axberger, Jerre \& Tham samt Jerre och, i ett nordiskt perspektiv, exempelvis Balvig m.fl. 
färdiga lösningen på kriminalpolitiska spörsmål (Ryssdal). I huvudsak kan dock de olika termerna kunna betraktas som i princip synonyma. Sarnecki, exempelvis, använder sig av både rättskänsla, rättsuppfattning och rättsmedvetande. Om inget särskilt anges används orden i det följande synonymt. ${ }^{4}$ En annan intressant fråga är om det alls går att tala om ett (gemensamt/allmänt) rättsmedvetande, eller om det i själva verket inte är så att finns flera beroende på skilda befolkningsgrupper. $^{5}$

\section{Bakgrund}

I rapporten Det allmänna rättsmedvetandet konstaterar Axberger inledningsvis att ARM inom juridiken inte är ett helt rumsrent begrepp beroende på tre saker av vilka problemet att definiera det är den första. Lyckas man väl definiera själva begreppet är det, för det andra, likväl svårt att fastställa innehållet i ARM. Den tredje saken som gör ARM problematiskt, menar Axberger, är att det kan föra tankarna till mystiska föreställningar om »folksjälen« och dylika begrepp vilka exempelvis spelade en roll för den nazistiska retoriken. Dessa tre betänkligheter gör att ARM kan riskera att användas »i tvivelaktiga syften, t.ex. av krafter som påstår sig känna 'det allmänna rättsmedvetandet' och i dess namn driver egna intressen eller idéer« (Axberger s. 7). Möjligen kan detta ha bidragit till att man åtminstone i den juridiska litteraturen tycks ha varit försiktig med att använda det.

Återkommande utpekas i sammanhanget tre aktörer nämligen politikerna/lagstiftarna, domarna/rättstillämparna och journalisterna/medierna (så hos t.ex. Ryssdal, Thelin). Jag kommer här i princip att helt bortse från den mellersta kategorin. Det som kan sägas om den här är att flagga för det riskfyllda med att låta rättsmedvetandet, åtminstone i betydelsen av tillfällig folkopinion, styra den dömande verksamheten. Här bör i stället krav på legalitet, objektivitet och rationella argument vara avgörande (Träskman 2015). Inte heller den både intressanta och underforskade frågan om mediernas roll i diskussioner kring kan beröras här. ${ }^{6}$ Helt kort kan dock konstateras att medierna tycks spela en roll inte bara som ob-

4. För en utförligare diskussion kring komplexiteten och tvetydigheten i de olika begreppen se t.ex. Ryberg 2006.

5. Wandall talar om en ökad kulturell och värderingsmässig diversitet i de skandinaviska länderna. Om hur vissa kulturella föreställningar kan prägla lekmannadomares allmänna rättsmedvetande, se Thelin.

6. För resonemang kring detta se t.ex. Träskman 2009. 
servatörer utan också aktörer. Betydelsen av ARM gör mediernas inflytande tydligt när medierna både skapar och redogör för ARM (Ryssdal).

\section{Legitimitet}

Varför det alls är av betydelse att lyssna till ARM är förstås det faktum att vi lever i en representativ demokrati. Lagen bör omsätta befolkningens uppfattning till praktisk politik. ${ }^{7}$ Politik som bedrivs utan ett folkligt stöd kan således inte rättfärdigas, vilket förstås äger giltighet även på kriminalpolitikens område. Thelin menar att i ett idealt tillstånd bör lagstiftaren (politikerna) spegla ARM eftersom riksdagens beslut är ett uttryck för folkviljan vilken också är ursprunget för den offentliga makten. Men, Thelin påpekar vidare att straffrätten är »utmejslad av juristtekniker« inom förvaltning och akademi samt att det inte sällan finns »ett betydande kunskapsunderskott hos de folkvalda« (Thelin s. 716). Men expertvälde andas å andra sidan demokratiunderskott, så det hela måste bli en fin balansgång mellan dessa båda alternativ.

Samtidigt är det inte riktigt så enkelt heller. Det är inte givet att allmänhetens syn på straff faktiskt bör påverka rättssystemet. Som den svenska tidigare justitieministern Laila Freivalds formulerat det är den rådande uppfattningen bland riksdagsledamöterna inte något självklart uttryck för vad människor $\mathrm{i}$ allmänhet tycker (Strömholm m.fl. s. 112). Samtidigt menar Kjelby \& Sæther politikernas uppfattning av vad som är rätt och fel och en rättfärdig behandling ett högst legitimt uttryck för ARM och citerar en dom som säger att »[d]ersom det ikke finnes holdepunkter for annet, må det verdisyn som er uttalt av Stortinget eller av en parlamentarisk utpekt regjering, kunne tas som et auktoritativt uttrykk for den alminnelige rettsfølelse« (Kjelby \& Sæther s. 169).

Man bör också fråga sig om ARM över huvud taget kan vara ett självständigt, rättsligt argument. Att lagstiftningen innehåller folkligt förankrad rättskänsla, uttryckt och använt som ett legitimt och politiskt argument, innebär inte att begreppet bör stå fritt från kritisk värdering (Blymke).

En annan intressant fråga kopplad till detta är om ARM också bör följas för det fall den allmänna opinionen exempelvis skulle svänga åt att återinföra dödsstraff eller införa sharialagar. Oavsett allvaret i sådana argument är det en grund för att vara skeptisk till betydelsen av ARM (Ryberg 2006). Det är en befogad fråga att ställa hur lagstiftaren skulle hantera en i dessa tider inte alls otänkbar situation där folkmajoritetens rättsuppfattning skulle vara »fel«. Man kan, mot

7. För djupare resonemang kring legitimitet rekommenderas Tankebe \& Liebling. 
bakgrund av utvecklingen i främst Ungern men även Polen, tänka sig en utveckling i högerpopulistisk riktning där ARM skulle kunna användas som argument för rättsliga sanktioner mot dissidenter.

\section{Det allmänna rättsmedvetandet i den rättsvetenskapliga litteraturen}

En viktig utgångspunkt i den moderna diskussionen kring ARM tycks vara Dag Victors inlägg vid det tjugonionde nordiska juristmötet 1981. Victor inleder med att konstatera att frågor kring rättsmedvetande på grund av sin relation till en viss normativ ordning inte hör hemma i ett vård- och behandlingsorienterat påföljdssystem. I den utveckling, som vid tidpunkten för artikeln var i full gång, i nyklassicistisk riktning mot straffvärde som grund för bedömningar i påföljdssystemet tar även frågan om rättsmedvetande en mer naturligt central plats menar Victor. Rättsmedvetandet kan antingen hänföra sig till en enskild person eller till en given kollektiv enhet och det är det senare som man kan beteckna som det allmänna rättsmedvetandet. Detta kan i sin tur uppfattas på två, helt principiellt skilda, sätt. Enligt det ena sättet, vilket också beskrivs som det dominerande, innebär att ARM »i princip att ett tillräckligt stort antal enskilda individer inom ett valt kollektiv (t.ex. medborgarna $i$ ett visst land) rent faktiskt har likartade attityder i 'rättsliga' frågor « (Victor s. 152). Synsättet, som kallas det reduktionistiska, låter sig således empiriskt bestämmas och utsättas för statistiska undersökningar. Det andra synsättet, vilket benämns det holistiska, har sitt ursprung i den s.k. historiska skolan där ARM ansågs utgå från »folkviljan« och inte bara utgjorde en rättskälla utan egentligen var den enda rättskällan. ${ }^{8}$ Enligt en av den historiska skolans främsta företrädare, F.C. von Savigny, återfanns dock inte det folkliga rättsmedvetandet hos de enskilda medborgarna utan »folket« var i stället en ideell storhet, präglad av ett nedärvt kulturellt sammanhang. En höjd kulturnivå hade medfört att en professionell juristkår uppstått och det var hos dem som ARM kunde återfinnas enligt Savigny. Det var således genom studier av den juridiska verksamhetens historia som rättsmedvetandet kunde hittas.

Det närmast metafysiska innehåll som $\mathrm{ARM}$ gavs av den germanskt präglade historiska skolan torde ha slagits sönder av den skandinaviska rättsrealismen. Victors inlägg blir intressant i sammanhanget eftersom han väver ihop den historiska skolan och det holistiska synsättet med det mer samhällsvetenskapligt inrik-

8. Rättskälla används här i sin ontologiska betydelse, som rättens verklighetsgrund. I den epistemologiska betydelsen, som kunskapsvägen till rätten, var sedvanerätten den främsta rättskällan (Victor s. 155). 
tade, empiriska reduktionistiska synsättet. Även om de båda synsätten ligger långt från varandra menar Victor nämligen att man inte nödvändigtvis måste göra ett val mellan dem: »De kan vara relevanta för olika sammanhang - för olika problemställningar« (Victor s. 158). För de flesta, menar Victor, framstår i dag den reduktionistiska bestämningen av ARM som självklar vilket också bekräftats av andra i hans efterföljd. Samtidigt varnar han för att fästa alltför stor tilltro till användbarheten av empiriska undersökningar. Dessa är behäftade med ett antal problem och får, enligt Victor, inte styra politiken utan får bara utgöra en - visserligen betydelsefull - del av kunskapsunderlaget vid beslutsfattandet. Victor talar också om att rättssystemet inte alltid bör anpassa sig till ARM. Dels kan missnöje med lagstiftningen bero på bristande kunskaper om problemens karaktär och rättsliga behandling (i sådana fall krävs information och insyn snarare än lagändring), dels kan det vara fråga om visserligen starka - men tillfälliga - opinionssvängningar vilka inte bör få genomslag. Här menar Victor att det är viktigt att även rättssystemet påverkar ARM och inte bara tvärtom. Han anser vidare att ett generellt avståndstagande från det holistiska synsättet vore olyckligt, även om en del av tankegodset förtjänar att avvisas, eftersom väsentliga inslag går att ta tillvara. Både av demokratiskäl som av skälet att systemet inte får bli ineffektivt menar Victor att det är av stor betydelse att straffrättskipningen inte i allmänhetens ögon framstår som orättfärdig eller obegriplig. Det är därför nödvändigt att den har kontakt med ARM (i reduktionistisk mening). Ett sätt för att skapa förtroende för straffsystemet hos ARM i den reduktionistiska betydelsen vore att utveckla ARM i den holistiska betydelsen, menar Victor och i den slutsatsen har han senare fått medhåll (Träskman 2015).

När hänvisningar till ARM görs från politiskt håll så vill man syfta på det reduktionistiska synsättet, dvs. att det finns ett faktiskt och påvisat stöd hos allmänheten för de önskade förändringarna. Men i själva verket är det nog snarast något som ligger det holistiska synsättet närmast som faktiskt åberopas. Påståendet om att politiska hänvisningar till ARM snarast påminner om det holistiska synsättet torde kunna göras gällande åtminstone om man godtar den skillnaden att det inte längre är hos den juridiska expertisen som man återfinner ARM utan hos politikerna själva. En sådan politisering, dvs. en förflyttning från experter till politiker som centrala aktörer i kriminalpolitiken är väldokumenterad (Andersson \& Nilsson). Experten är inte längre nödvändig för att legitimera kriminalpolitiken i en situation då ARM blivit politikens kunskapskälla där upplevelsen av brottsproblemet - uttryckt genom ARM - ställs mot forskningens beskrivningar; en kvalitativ aspekt ställs mot en kvantitativ (ibid). 
Här blir demokratifrågan igen relevant. Rättsmedvetandet kan, genom att det bär på några av våra demokratiska ideal, nämligen medborgarnas krav på inflytande över lagstiftningen, ses som ett uttryck för rättsstaten i sig (Blymke). Men politikern är vald av folket och anser sig därför kunna uttala vad ARM kräver (Balvig m.fl.). Politikern kan också hänvisa till ARM för att skapa eller framkalla sitt eget rättsmedvetande hos andra (Blymke). Huvudsyftet med den förda kriminalpolitiken kan sägas vara att sända signaler om t.ex. handlingskraftighet och man »behøver ikke eksperter til at fortælle sig, hvilke signaler man ønsker at sende. Det er baseret på intuition, på følelse, på retsfølelse« (Elholm s. 176). Det som återstår för experterna att göra när de ställs utanför den av ARM präglade kriminalpolitiken är att undersöka densamma (Balvig m.fl.).

I studier som försökt empiriskt undersöka ARM har rättsmedvetandet delats in i tre kategorier: det generella, det informerade och det konkreta (Balvig 2006). Det generella rättsmedvetandet är den rent övergripande inställningen till straff, exempelvis om de är för höga eller låga. Det informerade rättsmedvetandet är inställningen man har när ärendets grundläggande karaktär är känd och man systematiskt är informerad om de olika sanktionsmöjligheterna. Det konkreta rättsmedvetandet är, slutligen, den inställning man har till straff när man har ett konkret ärende man kan diskutera med andra och fatta beslut i som »domare«. Balvig (2015) har också introducerat begreppet retsfornuft vilket ställs emot rättskänslan av analytisk nödvändighet. Om (rätts)känslan är vår omedelbara, närmast reflexartade inställning till saker så är (rätts)förnuftet besinnad eftertanke och liknar på så sätt det informerade rättsmedvetandet. Eftersom resultatet kan förväntas bli radikalt olika beroende på om det är allmänhetens rättskänsla eller rättsförnuft - på samma sätt som vilken sorts rättsmedvetande (det generella eller det informerade) - man lyssnar till eller använder sig av är det viktigt att konstatera vilketdera det är fråga om i respektive fall. Kyvsgaard menar att det går en skiljelinje mellan det generella och det informerade rättsmedvetandet - mellan retsfølelse och retsfornuft - och att det är utifrån denna motsättning som det uppstår en »retsfølelsepopulisme« (Kyvsgaard s. 282).

Gröning menar att ARM faktiskt fyller en funktion om man tar det på allvar inte som en realitet utan som ett ideal. Hon menar vidare att ARM »om den skal ha eksistensberettigelse som et argument for straffelovgivning, [må] fungere som folkets korrektiv til lovgiveren« (Gröning s. 161). En sådan inställning förutsätter alltså att ARM fungerar i två riktningar och inte bara som en lagstiftarens legitimitetsgrund för straffskärpningar etc. I äldre texter - och i hänvisningar till desamma - tycks det vara vanligare med att hävda att ARM kan användas som argument både för och emot straffrättsliga åtgärder i form av straffskärpningar 
m.m. (se t.ex. Victor samt Träskman 1982 och Träskman 2015). Numera tycks tanken på att exempelvis avkriminalisera med hänvisning till ARM allt mer främmande. ${ }^{9}$ Att en fråga som den om illegal fildelning som tidigare varit het och kan antas ha (haft) en relativt stor tolerans hos stora delar av befolkningen ens skulle seriöst skulle tas upp för överväganden kring avkriminalisering bedömer jag som osannolikt. Utifrån resultat från t.ex. den stora nordiska undersökningen skulle man, om politikerna verkligen lyssnade till ARM, dock kunna argumentera för mildare straff generellt sett (Martinsson \& Anderberg).

Bondeson har i en av sina studier av rättsmedvetandet klargjort att frågan om hänvisningar till ARM fyller en teoretisk eller en ideologisk funktion är intressant ur rättspolitisk synpunkt. Hon konstaterar att ARM förefaller vara en »legal fiktion«, i meningen att den varken behöver vara sann eller falsk, och inte beskriver de verkliga förhållandena särskilt väl. Avståndet mellan teori och empiri är stort när det kommer till begreppets verklighetsbeskrivning vilket gör att man kan misstänka att ARM används ideologiskt. Bondesons egen undersökning ger anledning att tro att hänvisningar till ARM »snarast är ett sätt att argumentera som fyller ett legitimerande syfte" (Bondeson s. 141). ARM skulle närmast fungera som en rationalisering som tjänar politiska eller praktiska syften än att hänvisa till någon objektiv verklighet.

\section{Det allmänna rättsmedvetandet och förarbeten}

Detta skalkeskjul för ängsliga utredningsmän.

Stig Strömholm

Det bör inledningsvis framhållas att förarbeten eller lagmotiv har en framskjuten position i den nordiska rätten i allmänhet och den svenska rätten i synnerhet. En fråga som kan vara värd att ställa är om det går att utröna någon skillnad i hur ARM framställs i olika förarbeten, beroende på vem som är avsändare. Skulle det - om man får följa hypotesen att ARM uttrycks huvudsakligen från politiskt håll - återfinnas färre referenser till ARM i Statens offentliga utredningar (SOU), som i regel utarbetas av oberoende utredare/sakkunniga/experter, än vad som görs propositionerna som är departementsprodukter och således är närmare den politiska makten? I princip motsvarande frågeställning återfinns hos Ryssdal, men

9. En reservation måste kanske läggas in här då det inte är otänkbart att de argument för att avkriminalisera eget bruk av narkotika som gör sig allt mer gällande möjligtvis har en förankring $\mathrm{i}$ - och skulle kunna motiveras utifrån - ARM. 
svaret $\mathrm{i}$ hans fall blir att det inte går att få ett entydigt svar ur det undersökta materialet. Samtidigt bör påminnas om att direktiven till utredningarna har, åtminstone som det verkar, börjat formuleras snävare och i allt högre utsträckning liknar rena beställningsarbeten. ${ }^{10}$ Axberger menar att ARM kan förekomma i lagförarbeten, särskilt i den rättspolitiska argumentationen, men då huvudsakligen för att motivera en lagstiftningsåtgärd än för att ge uttryckliga direktiv till rättstil-lämparen.

Blymke behandlar i ett bokkapitel just frågan om känsla och rättskänsla i lagstiftnings-processen. Han visar på att det $\mathrm{i}$ en del förarbeten (lovutredningsarbeit) går att finna mer eller mindre direkt användning av - eller åtminstone hänvisningar till - ARM, vilka används som argument och ligger till grund för lagförslag. ARM blir på så sätt, menar Blymke, inte sällan åberopat och tas som intäkt för att lagförslaget har en solid förankring hos allmänheten. Särskilt ofta används ARM i samband med att konkreta straffbestämmelser diskuteras. Blymke visar, genom exemplifieringar ur ett antal lagstiftningsärenden, på hur politikers egna rättspolitiska ståndpunkter kan nå fram till folk i gemen genom att använda sig av känslobaserad juridisk argumentation. Även Kjelby \& Saether framhåller att det i samband med lagmotiv förekommer hänvisningar till ARM, särskilt som argument i skärpande riktning av såväl straffnivån som i påföljdshänseende.

De nyssnämnda studierna rör visserligen norskt lagstiftningsarbete men det finns ingen anledning att tro att förhållandena skulle vara annorlunda i Sverige. Tvärtom verkar det oerhört vanligt med den typen av hänvisningar åtminstone om man får tro Andersson \& Nilsson som menar att i stort sett alla lagstiftningspropositioner, i vart fall sedan 1980-talets mitt, »byggt på motiveringar som handlar om hur kriminalpolitiken måste ta hänsyn till eller motsvara allmänhetens uppfattning« (Andersson \& Nilsson s. 168). En viktig källa för detta påstående är Anderssons egen avhandling i vilken ståndpunkten att det inte (längre) är lagöverträdaren utan ARM som står i fokus för den svenska kriminalpolitikens omsorg befästs (Andersson). Om det främst är allmänheten som drivit på den alltmer straffinriktade utvecklingen eller om det politikerna som misstolkat - eller utnyttjat - allmänhetens oro för brott kan diskuteras.

Frågan om hänvisningar till ARM i förarbeten har också belysts från »insidan« genom att f.d. justitieministern Laila Freivalds uttalat sig i ämnet. Hon me-

10. Se, för exempel på detta, Nymansson. Ytterligare ett exempel är direktiven till den s.k. Ungdomsreduktionsutredningen (SOU 2018:85) där utredarens uppdrag på ett ovanligt tydligt sätt slogs fast (dir. 2017:122). 
nar att det är sällan själva begreppet (i just detta fall den allmänna rättsuppfattningen) används i förarbeten men att det i antaganden och överväganden döljer sig i olika uttryck som »stötande«, »rimligt«, »oskäligt« etc. (Strömholm m.fl. s. 111). Freivalds menar vidare att man dock undviker begreppet särskilt vid straffrättslagstiftning eftersom det lätt anses liktydigt med straffskärpningar, vilket kanske inte är så märkvärdigt egentligen. Victor menar nämligen att resonemang kring ARM i betydande omfattning är överförbara till frågan om straffvärde eftersom rättsmedvetandet i straffrättsliga sammanhang av naturliga skäl huvudsakligen kommer att gälla straffvärdefrågor. Graden av straffvärde måste visserligen inte nödvändigtvis handla om straffskärpningar, men gör det påfallande ofta.

Någon närmare studie av tidigare svenska förarbeten kan av förklarliga skäl inte tillåtas här. ${ }^{11}$ Det går dock inte att kringgå några förarbeten som ligger nära, men likväl före undersökningsperioden. Efter regeringsskiftet 2006 kom en skärpt syn på främst brotten mot person att prägla kriminalpolitiken. I kommittédirektivet till Straffnivåutredningen angavs att utredaren skulle »överväga och föreslå förändringar av strafflagstiftningen i syfte att åstadkomma en straffmätning som markerar en skärpt syn på allvarliga våldsbrott« (dir. 2007:48). Ett centralt, och i flera efterföljande förarbeten återkommande, påstående i direktivet är att »[s]amhällsutvecklingen medför förändringar i synen på olika brotts straffvärde«. Straffnivåutredningens slutbetänkande Straff $i$ proportion till brottets allvar (SOU 2008:85) ingår i undersökningsperioden och redogörs därför för närmare nedan. Dock presenterades redan i slutet av 2007 ett delbetänkande, Straffskalan för mord (SOU 2007:90), vilket till viss del gav en föraning om vad som komma skulle. Att acceptansen för våld har minskat i samhället avspeglade sig, menade man, bl.a. i en ökad anmälningsbenägenhet. Mot bakgrund av ett ökat samhälleligt välstånd kunde våldsbrott betraktas som ett större hot mot den enskilde, sett $\mathrm{i}$ förhållande till t.ex. de rena förmögenhetsbrotten. Även det att individens rättigheter har förstärkts i förhållande till kollektiva intressen ansågs ligga i linje med den minskade acceptansen för våld och den var främst det sistnämnda som ansågs motivera en skärpt syn på allvarliga våldsbrott (SOU 2007:90 s. 135). Uttalandet kom att ligga till grund för resonemang i åtskilliga kommande förarbeten.

11. Fängelsestraffkommitténs betänkande (SOU 1986:14), som låg till grund för 1989 års straffvärdereform, har annars anförts som ett exempel på när ARM lyst igenom i lagstiftningssammanhang. Se särskilt a.a., s. $43 \mathrm{f}$. 


\section{Undersökningen}

Ett sätt att utföra en undersökning av det här slaget vore att använda sig av diskurs- eller begreppsanalys. De metodologiska och (vetenskaps)teoretiska krav en sådan studie skulle fordra har dock inte varit möjliga att genomföra fullt ut inom ramen för projektet. I stället har undersökningen utförts genom initiala sökningar på nyckelord ${ }^{12} \mathrm{i}$ drygt 70 förarbeten på straffrättens område. ${ }^{13}$ Nyckelorden har valts ut utifrån att de, eller snarlika begrepp, betraktats antingen som synonyma med eller som uttryck för ARM (Hermansson s. 3 samt Jönsson s. 64 [not 214] och 87). Efter den initiala sökningen har de förarbeten som utifrån nyckelordsträffar framstått som innehållande uttryck för ARM, vilket var knappt 30 stycken, studerats lite närmare. Förarbetena har presenterats under senare hälften av 2008 till och med första hälften av 2018 och följer därmed i princip riksdagsåren (dvs. propositioner från 2008/09 är de första som tas med och från 2017/18 de sista). ${ }^{14}$ Det blir således tio års förarbeten som undersöks, vilket förefaller vara en lämplig avgränsning. De är tämligen aktuella men spänner ändå över en tidsperiod som tillåter endast försiktiga uttalanden om tendenser, även om det huvudsakligen blir fråga om en samtidsbild. ${ }^{15}$

Det uttalande från Straffnivåutredningens delbetänkande SOU 2007:90 som citerats ovan reproduceras på ett eller annat sätt i flera efterföljande förarbeten. Redan i SOU 2008:81 finns det hänvisat till och så fortsätter det i t.ex. Ds

12. Följande nyckelord har använts (i bokstavsordning): acceptans, allmänhetens uppfattning, nyanserad straffmätning, rättskänsla, rättsmedvetande, rättsuppfattning, samhällets syn på, samhällssynen, skärpt syn, synen på samt tolerans.

13. Med »straffrättens område« avses här primärt förarbeten från Justitiedepartementet som behandlar straffrättsliga frågor. Det finns dock utredningar med straffrättslig relevans som av olika anledningar sorterat under andra departement. Som ett exempel utgavs SOU 2015:103 Ett utvidgat straffrättsligt skydd för transpersoner m.m. av Kulturdepartementet. Budgetpropositioner har inte tagits med i undersökningen.

14. Startpunkten, får medges, är dock inte alldeles slumpvis vald. Hösten 2008 presenterade nämligen den s.k. Straffnivåutredningen sitt betänkande Straff i proportion till brottets allvar (SOU 2008:85) vilket i efterhand har framstått som ett av de tydligaste exemplen på hur lagstiftaren motiverat straffskärpningar utifrån just det allmänna rättsmedvetandet. Det föreföll därför lämpligt att detta utredningsbetänkande skulle omfattas av undersökningen.

15. Det kan parentetiskt nämnas att det, liksom i Ryssdals ovan berörda fall, inte går att dra några entydiga slutsatser kring om det skulle finnas färre hänvisningar i expertledda utredningar än i mer politiknära propositioner. Inte minst är materialet förhållandevis begränsat. Av de närmare studerade förarbetena i min undersökning är det i princip hälften propositioner/promemorior och hälften offentliga utredningar. 
2013:55 och SOU 2014:49. Det var, som vi sett ovan, redan i direktiven till Straffnivåutredningen som tonen hade anslagits. För att kunna ta ställning till hur en sådan önskad skärpt syn skulle komma till uttryck övervägde utredningen vilka skäl som talade för skärpta straff för allvarliga våldsbrott samt styrkan hos skälen. Dels undersöktes vilka förhållande som borde tillmätas relevans vid bedömningen av straffnivåerna, dels i vilken grad dessa förhållandet ändrats på ett sådant sätt som skulle motivera en förändrad straffnivå. I huvudbetänkandet SOU 2008:85 konstaterades att straffet bör spegla hur allvarligt samhället ser på den brottsliga gärningen samtidigt som det måste råda en relativ proportionalitet mellan olika brott. Detta innebar, ansåg man, att det är samhällets syn på olika brott som borde läggas till grund för översynen av straffsystemet. Om - och i så fall på vilket sätt - någon skillnad föreligger mellan »samhällets syn « och ARM framgår egentligen inte. Jag ser det som två sätt att uttrycka samma sak och betraktar dem därför som synonyma.

Utredningen ansåg vidare att det var mycket svårt att påvisa brottspreventiva effekter vid ändrad lagstiftning.

Intressant nog framhålls också i utredningen vanskligheten av att lägga allmänna omdömen om rättstillämpningen i enskilda fall, vilka beskrivs som ett uttryck för ARM, till grund för reformer. Lagstiftningen kan vara rimlig och ändamålsenlig även om det förekommer enskilda fall som inte leder till önskvärda resultat. Dessutom, anför man, är ett annat skäl till att inte lägga ARM till grund för reformer »att det är mycket svårt att fastställa vad det allmänna rättsmedvetandet säger i en viss fråga«, beroende på att människors uppfattning tenderar att påverkas utifrån bl.a. perspektiv (SOU 2008:85 s. 247).

Som det främsta skälet för skärpta straff anfördes den över tid förändrade syn som innebar att allvarliga våldsbrott bedömdes mer förkastliga än tidigare. Även starka brottsofferhänsyn togs liksom en hänvisning till risk för att kriminella organisationers ställning skulle befästas vilket kunde vara ett hot mot såväl rättstryggheten som andra grundläggande demokratiska värden. Trots detta menade utredningen att det inte fanns tillräckligt underlag för att brottsutvecklingen $i$ sig kunde motivera en straffskärpning. Inte heller ansågs en generellt höjd straffnivå för allvarliga våldsbrott motiveras utifrån förväntningar om minskad brottslighet. Sambandet mellan straffnivå och brottsutveckling ansågs erfarenhetsmässigt vara så svagt att det endast i speciella situationer skulle kunna anföras som en saklig grund för straffskärpning (SOU 2008:85 s. 258).

I ett särskilt tillägg (till ett särskilt yttrande) till betänkandet beklagade experten Petter Asp först att utredningsdirektiven inte givit utrymme åt lösningar som inte enbart bygger på straffskärpningar. Sådana lösningar, menade Asp, kunde 
möjligen ligga i linje med den allmänna opinionen men hänvisade till vetenskapliga undersökningar som visat på att allmänhetens syn på straff är betydligt mer nyanserad än vad man kanske tror. Asp varnade vidare för den »repressionsspiral« som drar igång när straffen aldrig uppfattas som tillräckligt hårda. Att starkt reagera mot allvarliga brott är naturligt, menade Asp, »men dessa känslor bör inte ensamma läggas till grund för bedömningen av vart den allmänna repressionsnivån skall läggas« (SOU 2008:85 s. 403).

Straffnivåutredningens sätt att tillmäta betydelsen av ekvivalens och proportionalitet har kritiserats. Politikernas fokus har, enligt kritiken, hamnat på att möta det allmänna rättsmedvetandets krav istället för att föra principiella diskussioner kring hur proportionalitet kan etableras och hur straffvärden för olika brott relaterar till varandra. ARM liknas vid en marknad där väljarna ses som medvetna och krävande kunder. Proportionalitet blir, på en sådan marknad, något som avgörs av kunden. Den förda politiken leder då till att »skjuta proportionalitetsprincipen i bitar genom att göra den relativ till, inte brottets allvarlighet relativt till handlingens förtjänstvärde, utan till vad 'allmänheten' tycker om detta « (Andersson \& Nilsson s. 221. Min kursivering).

I den efterföljande propositionen (2009/10:147) återkom naturligt nog argumentationen från utredningen. Det tillades också att den generellt strängare synen på brotten inte återspeglades i domstolarnas praxis, trots att utrymme för det fanns i straffskalorna. ${ }^{16}$ Formuleringarna återkommer även i senare förarbeten. I SOU 2014:18, Straffskalorna för allvarliga våldsbrott, citerades den nyss nämnda propositionen och det konstateras i en artikel året därpå att man med citatet »uppenbart [...] hänvisar till det allmänna rättsmedvetandet och förändrade värderingar som kommer till uttryck i detta« (Träskman 2015 s. 428). Straffen för vissa våldsbrott förtjänar, utifrån argumentationen, att skärpas men inte men inte utifrån brottspreventiva skäl utan av det skälet att alltför låga straff skulle kränka allmänhetens rättskänsla.

En stark opinion kan ha påverkan på lagstiftningen. Så tycks fallet ha varit vid den senaste reformeringen av sexualbrottsbestämmelserna i brottsbalken. 2014 års sexualbrottskommitté uttalade i sitt betänkande att ett antal uppmärksammade rättsfall föranlett kraftiga reaktioner från allmänheten och att en debatt kring fallen blossat upp i såväl de traditionella medierna som i sociala medier. Det som

16. Praxis hade undersökts i Åklagarmyndighetens rapport Domstolarnas påföljdspraxis vid vissa våldsbrott (2007). För transparensens skull kan nämnas att jag var anställd som beredningsjurist i detta uppdrag. 
där framgått var att allmänhetens syn på sexualbrott inte stod i överensstämmelse med lagstiftningen och man varnade för att förtroendet för lagen och rättskipningen kunde minska om avståndet mellan allmänhetens rättsmedvetande och lagen var för stort. Kommittén bedömde att det rörande frågan om ansvar för sexualbrott föreföll vara ett alltför stort sådant glapp vilket, jämte även vissa andra bedömningsgrunder, gjorde det befogat att införa ett oaktsamhetsansvar i sexualbrottslagstiftningen (SOU 2016:60 s. 262).

Sammanfattningsvis kan sägas att Straffnivåutredningens betänkande(n) starkt präglat de efterföljande förarbeten som innehållit explicita eller implicita hänvisningar till ARM. Det är således svårt att separera de senare från 2008 års utredning och därigenom definitivt säga något om hänvisningarna så att säga är självständiga eller i princip bara reproducerade. Några riktiga slutsatser kring omfattningen av referenser till ARM i förarbeten under den undersökta perioden torde därför vara svåra att dra. Men det faktum att hänvisningarna till ARM har reproducerats ger samtidigt intrycket att man från lagstiftarens sida tycks se det som en viktig och legitim grund att motivera författningsförslag på.

\section{Avslutning}

Henvisninger til rettsbevisstheten er et ledd i en argumentasjonsteknikk og ikke et program for undersøkelse av folks faktiske holdninger.

Vilhelm Aubert

Auberts uttalande ovan har också citerats i Bondesons tidigare nämnda utredning, och det är inte svårt att, även utifrån den här genomförda studien, förstå och instämma i såväl Auberts som Bondesons (snarlika) ståndpunkt. De flitigt återkommande hänvisningar som i de undersökta förarbetena görs till ett mycket vagt definierat rättsmedvetande tycks just vara mer av känslomässigt styrd argumentation än faktabaserat underlag för ny lagstiftning. Orsakerna till detta är flera och omdiskuterade. En förklaring ligger i att det såklart är både svårt och omständligt att faktiskt fastslå vad allmänheten tycker i en viss fråga. Dessutom finns ju risken att, om frågan verkligen undersöks, allmänheten faktiskt tycker något annat än den tänka politiska linjen och argumentet skulle gå förlorat. Bättre, ur politisk synvinkel, är då att helt enkelt på egen hand fastslå att det är på ett visst sätt och därefter reproducera åsikten till dess att den blir sanning. Intrycket att det rättsmedvetande som används ligger det holistiska synsättet närmast stärks, även om det nog inte är avsikten. Tvärtom.

I den juridiska traditionen finns en vilja att, i den mån man alls befattar sig med begreppet, prata om ARM som ett empiriskt begrepp men man har inte i till- 
räcklig mån lyckats med att behärska metoden. Genom den nyklassicistiska skolan togs ARM åter upp och kom att nära förknippas med straffvärdereformen.

Den omständighet att ARM:s innehåll i princip inte låter sig fastställas är problematisk i det att ARM ofta används som grund för förändring i lagstiftningsärenden. Om det närmare innehållet $\mathrm{i}$ ett argument inte låter sig bestämmas blir det i praktiken omöjligt att säga emot. Här kommer också demokratiaspekten in. Sätter man sig emot ARM - hur vagt formulerat det än är - sätter man sig indirekt också emot folkstyret. Men fastställs inte innehållet blir argumentet också innehållslöst.

Jag kan avslutningsvis instämma i Linda Grönings uttalande i en bilaga till utredningen Skyldevne, sakkyndighet og sammfunnsvern där hon formulerar det som att lagstiftaren som utgångspunkt bör vara försiktig med att basera regler på argument om vad ARM eller brottsofferperspektivet kräver - »til det er samfunnets kompleksitet for stor« (NOU 2014:10 s. 422).

\section{Referenser}

Andersson, R. (2002) Kriminalpolitikens väsen. Stockholm: Kriminologiska institutionen.

Andersson, R. \& Nilsson R. (2017) Svensk kriminalpolitik, 2 uppl., Malmö: Liber.

Aubert, V. (1976) Rettens sosiale funksjon. Oslo: Universitetsforlaget.

Axberger, H.G., (1996) Det allmänna rättsmedvetandet. BRÅ-rapport 1996:1. Stockholm. https://doi.org/10.1016/S0294-3506(96)80230-4

Balvig, F. (2006) Danskernes syn på straf. København: Advokatsamfundet.

Balvig, F. (2015) Retsfølelse og retsfornuft - i Danmark. Metoder og materialer 2006 og 2009. Nordisk Samarbejdsråd for Kriminologi.

Balvig, F., Gunnlaugsson, H., Jerre, K., Olaussen, L.P. \& Tham, H. (2010) »Den nordiske retsbevidsthedsundersøgelse«. I: NTfK 3/2010 s. 232-250.

Blymke, Ø. (2016) »Personvern og rettssikkerhet i rettspolitikken: om følelser og rettsfølelse i lovgivningsprosesser«. I: Frøseth, A.M., Gröning, L. \& Wandall, R.H. (red.) (2016) Rettsfølelsen i strafferettssystemet - perspektiver fra teori og praksis. Oslo: Gyldendal juridisk, s. 110-136.

Bondeson, U. (1979) »Det allmänna rättsmedvetandet - en legal fiktion«. I: Bondeson, U. (red.) Rationalitet i rättssystemet. Stockholm: Liber, s. 123-145.

Dir. 2007:48. Skärpt syn på allvarliga våldsbrott m.m. Kommittédirektiv.

Dir. 2017:122. Skärpta regler för lagöverträdare 18-20 år. Kommittédirektiv.

Ds 2007:31. Straffet för mord.

Elholm, T. (2011) »Rimer signal på kriminal? Om symbol- og signallovgivning i dansk kriminalpolitisk perspektiv«. I: Andersson, U., Wong, C. \& Örnemark Hansen, H. (red.) Festskrift till Per Ole Träskman. Stockholm: Norstedts juridik, s. 166-178.

Frøseth, A.M., Gröning, L. \& Wandall, R.H. (red.) (2016) Rettsfølelsen i strafferettssystemet perspektiver fra teori og praksis. Oslo: Gyldendal juridisk. 
Gröning, L. (2016) »Er de norske utilregnelighetsreglene i strid med rettsfølelsen?«. I: Frøseth, A.M., Gröning, L. \& Wandall, R.H. (red.) (2016) Rettsfølelsen i strafferettssystemet - perspektiver fra teori og praksis. Oslo: Gyldendal juridisk, s. 137-165.

Hermansson, K. (2009) Synen på straff. En metodstudie baserad på vinjetter. Examensarbete. Stockholm: Kriminologiska institutionen.

Jerre, K. (2013) The Public's Sense of Justice in Sweden - a Smorgasbord of Opinions. Stockholm: Kriminologiska institutionen.

Jerre, K. \& Tham, H. (2010)»Svenskarnas syn på straff«. Rapport 2010:1 Stockholm: Kriminologiska institutionen.

Jönsson, K. (2018) Den avideologiserade straffrätten. En straffrättsideologisk analys av 2000talets straffskärpningar. Examensarbete. Lund: Juridiska fakulteten.

Kyvsgaard, B. (2011) »Kriminologiens betydning i en forandret verden«. I: Andersson, U., Wong, C. \& Örnemark Hansen, H. (red.) Festskrift till Per Ole Träskman. Stockholm: Norstedts juridik, s. 277-285.

Lindén, P.A. \& Similä, M. (1982) Rättsmedvetandet i Sverige. Brå Rapport 1982:1.

Martinsson, D. \& Anderberg, A. (2018) »Hårdare tag i valårets tecken. Ett kritiskt inlägg om den senaste tidens straffrättspolitik«. JT 2017/18 nr 4 s. 921-938.

NOU 2014:10. Skyldevne, sakkyndighet og samfunnsvern.

Nymansson, E. (2020) »Remissfasen och Lagrådets roll«. I SvJT 1/2020 s. 34-38.

Ryberg, J. (2006) Retsfølelsen. En bog om straf og etik. Roskilde: Roskilde universitetsforlag.

Ryberg, J. (2016) »Retsfølelse og kriminalpolitik«. I: Frøseth, A.M., Gröning, L. \& Wandall, R.H. (red.) (2016) Rettsfølelsen i strafferettssystemet - perspektiver fra teori og praksis. Oslo: Gyldendal juridisk, s. 29-46.

Ryssdal, A (2008) »Den allmenne rettsfølelse - veiviser eller villeder i strafferetten? I: Kritisk Juss nr. 1/2008, s. 6-35.

Sarnecki, J. (2017) Brottsligheten och samhället. 2 uppl. Lund: Studentlitteratur.

SOU 1986:14. Påföljd för brott.

SOU 2007:90. Straffskalan för mord.

Strömholm, S., Freivalds, L. \& Nycander, S. (2001) »Skall lagreglerna spegla eller påverka den allmänna rättsuppfattningen?«. I SvJT 2001 s. 101-120.

Tankebe, J. \& Liebling, A. (red.) (2013) Legitimacy and Criminal Justice: an International https://doi.org/10.1093/acprof:oso/9780198701996.001.0001 Exploration. Oxford: Oxford University Press.

Thelin, K. (2018) »Var hittar vi det allmänna rättsmedvetandet? Några reflektioner i anledning av en tingsrättsdom«. I: Banakar, R., Dahlstrand, K. \& Ryberg-Welander, L. (red.) Festskrift till Håkan Hydén, Juristförlaget i Lund, 2018, s. 713-723.

Träskman, P.O. (1982) »Straffrättens stigma«. I: Lov og frihet - Festskrift till Johs. Andenaes på 70-årsdagen. Oslo: Universitetsförlaget, s. 371-384.

Träskman, P.O. (2009) »Vem är kriminalpolitikens nyckelperson: brottslingen, brottsoffret eller 'jag' själv?« JT 2008/09 nr. 3 s. 497-515.

Träskman, P.O. (2015) »Skapas det allmänna rättsmedvetandet av att vi är medvetna eller omedvetna?« SvJT 2015 nr 5-6, s. 428-439.

Träskman, P.O. (2018) »Ett påföljdssystemet [sic] där en återfallsbrottsling inte döms till strängare straff saknar trovärdighet!«. I: NTfK nr 3/2018 s. 240-253. 
Victor, D. (1982) »Rättsmedvetande och straffvärde«. I: Förhandlingarna vid Det tjugonionde nordiska juristmötet i Stockholm 19-21 augusti 1981. Del II, s. 151-168.

Wandall, R.H. (2016) »Det 'almene' i den almene retsfølelse - og legitimitet under tiltagende kulturel diversitet.« I: Frøseth, A.M., Gröning, L. \& Wandall, R.H. (red.) (2016) Rettsfølelsen i strafferettssystemet - perspektiver fra teori og praksis. Oslo: Gyldendal juridisk, s. 7498.

Förarbeten som efter initial sökning studerats närmare (de som refereras till i texten markeras med asterisk)

Ds 2009:17 Straffrättsliga åtgärder till förebyggande av terrorism.

Ds 2011:1 Olovlig fotografering.

Ds 2013:55 Skärpt straff för mord.*

Ds 2017:24 Skjutvapen och explosiva varor - Skärpta straff för de grova brotten.

Ds 2017:38 Livstidsstraff för mord.

Ds 2018:23 Vissa frågor om barnpornografibrottet och om avskaffad preskription för allvarliga brott mot barn.

Ds 2018:29 Brott mot förtroendevalda.

Prop. 2008/09:118 Straffet för mord m.m.

Prop. 2009/10:147 Skärpta straff för allvarliga våldsbrott m.m.*

Prop. 2013/14:194 Skärpt straff för mord.

Prop. 2016/17:108 Straffskalorna för vissa allvarliga våldsbrott.

Prop. 2016/17:131 Grovt fordringsbedrägeri och andra förmögenhetsbrott.

Prop. 2016/17:222 Ett starkt straffrättsligt skydd för den personliga integriteten.

Prop. 2017/18:26 Skjutvapen och explosiva varor - skärpta straff för de grova brotten.

Prop. 2017/18:177 En ny sexualbrottslagstiftning byggd på frivillighet.

SOU 2008:81 Stalkning - ett allvarligt brott.*

SOU 2008:85 Straff i proportion till brottets allvar.*

SOU 2010:38 Mutbrott.

SOU 2010:71 Sexualbrottslagstiftningen - utvärdering och reformförslag

SOU 2011:16 Allmän skyldighet att hjälpa nödställda?

SOU 2011:85 Fridskränkningsbrotten och egenmäktighet med barn.

SOU 2013:7 Skärpningar i vapenlagstiftningen.

SOU 2013:38 Vad bör straffas? I-II.

SOU 2013:85 Stärkt straffrättsligt skydd för egendom.

SOU 2014:7 Skärpta straff för vapenbrott.

SOU 2014:18 Straffskalorna för allvarliga våldsbrott.*

SOU 2014:49 Våld i nära relationer - en folkhälsofråga.*

SOU 2016:42 Ett starkt straffrättsligt skydd mot köp av sexuell tjänst och utnyttjande av barn genom köp av sexuell handling, m.m.

SOU 2016:60 Ett starkare skydd för den sexuella integriteten.* 